\title{
Shunting Locomotives Fuel and Power Resources Decrease
}

\author{
M.O. Mussabekov ${ }^{1}$, G.B. Bakyt ${ }^{2}$, A.M. Omirbek ${ }^{1}$, Eva Brumerčíková, ${ }^{3, *}$, and Bibiána \\ Buková $^{3}$ \\ ${ }^{1}$ Kazakh Transport and communication Academy, Faculty of Automation and Telecommunications, \\ Shevchenko Street 97, Kazakhstan \\ ${ }^{2}$ Karagnada State Technical University, Mira Avenue 56, Karagandy 100000, Kazakhstan \\ ${ }^{3}$ University of Žilina, Faculty of Operation and Economics of Transport and Communications \\ Department of Railway Transport, Univerzitná 1, 01026 Žilina, Slovakia
}

\begin{abstract}
The article discusses about the increase in operational fuel consumption of shunting locomotives in the cold season. Possible solutions to this problem through the use of diesel engines with dry crankcase are considered. The technique of evaluating the thermal state of the diesel engine and the calculation of fuel consumption of heating boiler are provided.
\end{abstract}

\section{Introduce}

Railway transport is carrying out more than $70 \%$ of transportation in Kazakhstan, and, therefore, it is one of the major consumers of fuel and power resources (F\&PR) of the country. More than $50 \%$ of transportation process is carried out by locomotives.

An integral part of transportation process is shunting operation. It grows along with the development of transportation, increase in network spread and number of stations performing technical and commercial operations. Shunting operations are performed by diesel locomotives only. The main operator of transportation process in Kazakhstan railroads, providing with locomotive traction, is JSC "Locomotive", and its annual fuel consumption makes $700 \div 800$ thousand tons. Taking into account the fact that $40 \div 50 \%$ of all railroads operating costs in Kazakhstan consist of fuel consumption and locomotives power supply, it is obvious that saving of fuel and power resources (F\&PR) is an important reserve for energy efficiency increase.

\section{The total fuel quantity, consumed by diesel locomotives}

The total fuel quantity, consumed by diesel locomotives, is based on fuel consumption by operation type

\footnotetext{
*Correspondig author : eva.brumecikova@fpedas.uniza.sk
} 


$$
\mathrm{E}_{\mathrm{T}}=\sum_{i=1}^{n} G_{i}
$$

where: $\mathrm{Gi}$ - locomotive fuel consumption by operation type (cargo, passenger, shunting and administrative), $\mathrm{kg}$.

Diesel locomotives effective use common criteria is specific fuel consumption per 10000 tons kilometers (gross).

$$
\mathrm{e}_{\mathrm{t}}=\frac{E_{T}}{\mathrm{~A}} \cdot 10^{4}, \quad \frac{\mathrm{kg}}{10^{4} \text { t km gross }}
$$

where: A - annual locomotive scope of work by operation type, million ton kilometers (gross) [1].

The scope of work of JSC "Locomotive" diesel locomotives in 2015 was 208264.6 million tons kilometers (see Fig. 1) with 727,117 tons of fuel consumption and average specific fuel consumption $34.9 \frac{\mathrm{kg}}{10^{4} \mathrm{t} \mathrm{km} \text { gross }}$ (see Fig. 2).

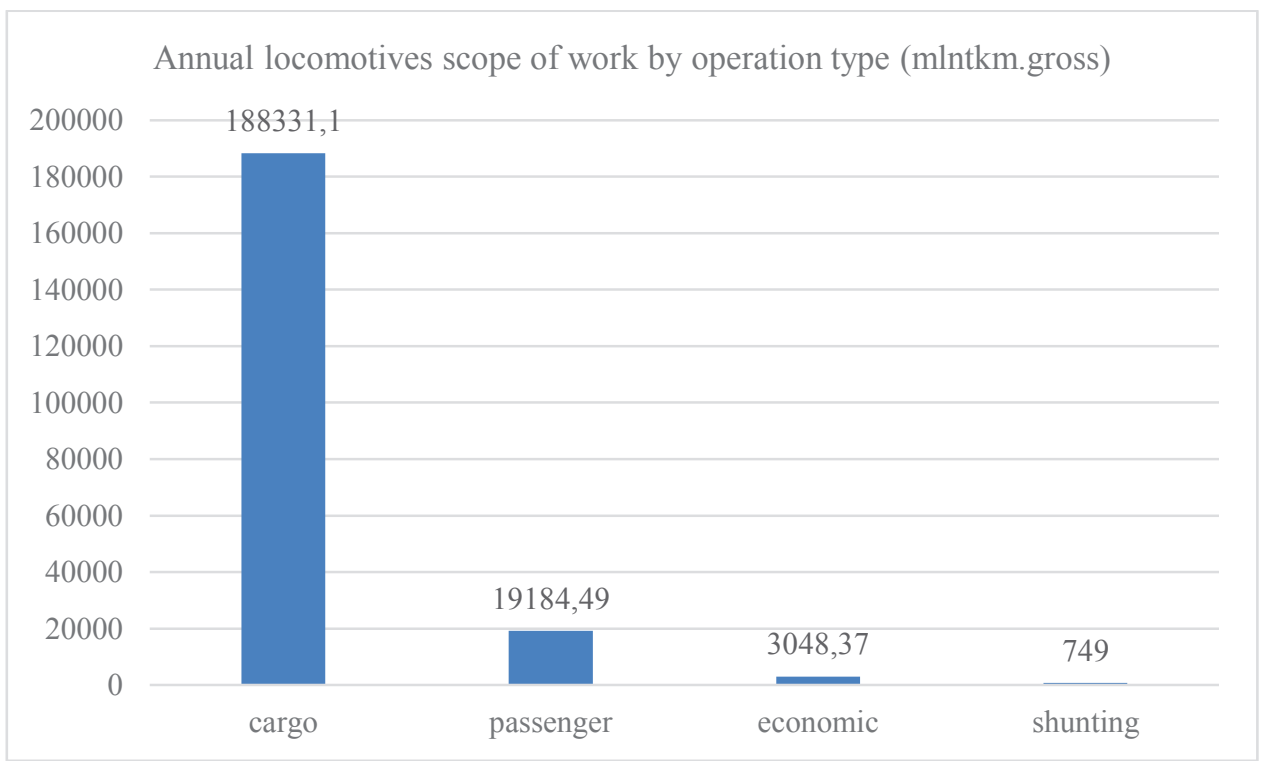

Fig. 1. Annual locomotives scope of work by operation type. Source: authors 


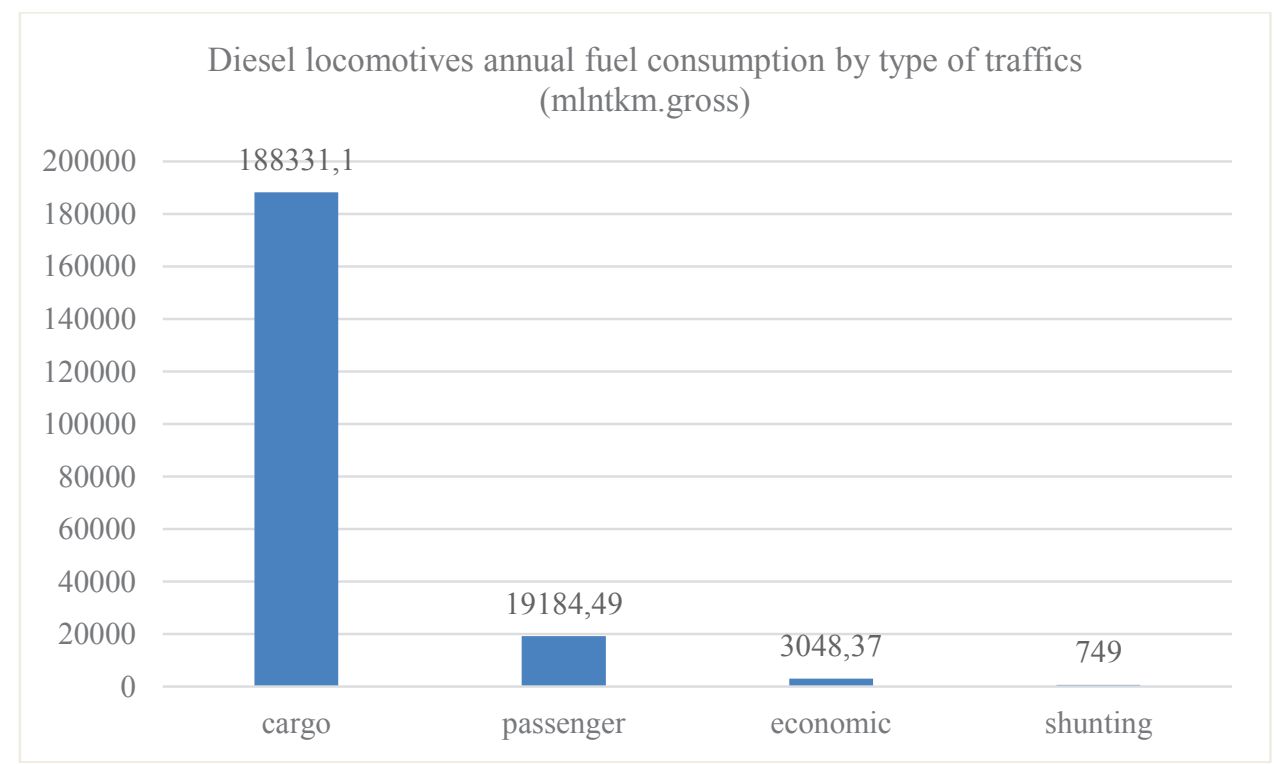

Fig. 2. Diesel locomotives annual fuel consumption by type of traffics. Source: authors

\section{Efficiency of diesel locomotives}

Efficiency of diesel locomotives utilization capacity is determined by DGU (diesel generator unit) - K load factor.

$$
\mathrm{K}=\frac{N_{\text {int.p }}}{N_{\text {nom }}}
$$

where: $N_{\text {int.p }} \quad$ - intermediate power, kW;

$N_{\text {nom }}$ - nominal power, $\mathrm{kW}$.

Locomotives GDU (diesel generator unit) loading at different operation types have the following average values:

- cargo $\mathrm{K}=0.7 \div 0.9$,

- passenger $\mathrm{K}=0.5 \div 0.7$,

- administrative $\mathrm{K}=0.3 \div 0.4$,

- shunting $\mathrm{K}=0.2 \div 0.3$.

This information shows the non-economic operation mode of locomotives DGU, especially at shunting and administrative operations.

The characteristic feature of shunting locomotives operation is the fact that idling and small loadings make $60 \div 75 \%$ of overall work duration, DGU nominal mode makes $1.5 \%$ of locomotive overall operating time [2].

Such shunting diesel locomotives engine operational modes distribution is noted also in some other operations [2-6]. It is determined by train and shunting operational conditions and temporary (seasonal) factors as well. Fuel consumption at the idling mode of the diesel engine is $30 \div 50 \%$ of the total fuel consumption in operation [2, 4]. As a result, shunting diesel locomotives specific fuel consumption exceeds specific expense of mainline diesel locomotives in cargo operations by 10.6 times (Fig. 3). 


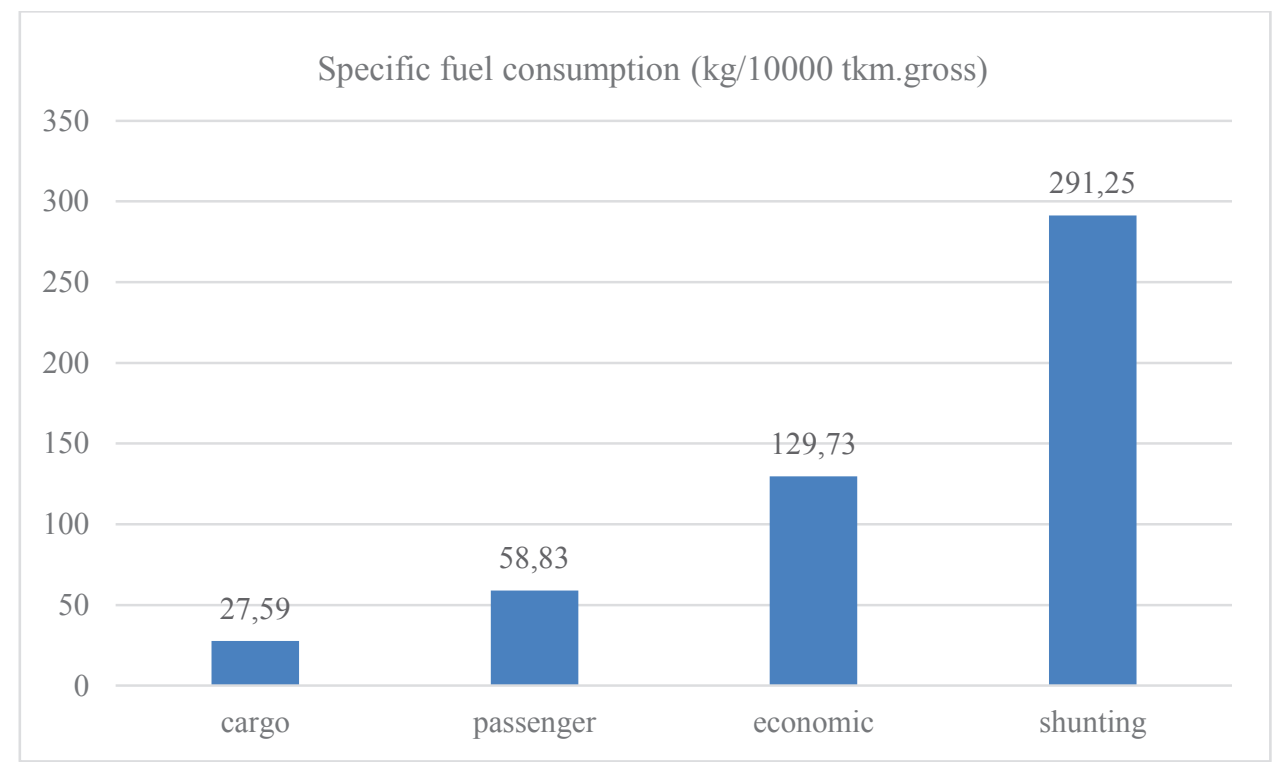

Fig. 3. Diesel locomotives specific fuel consumption by diverse traffics. Source: authors

Increased fuel consumption is not the only negative consequence of engine operations with small loadings and idling. It is combined with an intensive carbonizing in turbo compressor that leads to the rotor imbalance, productivity and air pressure decrease and, as a result, to the increased depreciation of supporting bearings in turbo compressor, engine fuel consumption increase in all capacity range, increased thermal stress of sleeve assembly, and increase of emissions release into the atmosphere. Currently, it is offered a large number of projects to reduce the fuel consumption by the shunting locomotive engine at idling during the hot idle, reduce carbon formation by reducing the overhaul periods of turbo compressor or injecting water into it, etc. [5]. Considerable decrease in operational efficiency and respectively shunting diesel locomotives huge fuel consumption occurs at low air temperature. Danger of water freezing in cooling system and high oil viscosity at low temperatures do not allow switching the engine off. The use of antifreeze in the existing locomotive diesels is economically and functionally impossible. There are very many various heating systems of switched off diesel engines. For example, American company Kim Hotstart's system is widely used; where the main heating sources are electric heating tubes installed in diesel cooling system and powered by additional DGU of small capacity [6].

The system of autonomous diesel heating of the locomotive called "Gulf Stream" which is developed by "Delway Management" [4] uses as a source of heating the heat exchange units (fuel combustion energy is converted directly to heat).

Fundamental faults of these systems are the following:

- low efficiency due to energy conversion,

- frequent maintenance of additional DGU,

- use of the additional device required for oil heating in a diesel engine.

The main consuming part of locomotives is the diesel engine.

The analysis of chronometer data shows that:

- first - idling corresponds to waiting time of locomotive, i.e. the locomotive stands idle,

- second - nominal power (for example $880 \mathrm{~kW}$ of diesel PD1M - TEM2 locomotive) practically is not used, i.e. shunting locomotives DGU is operated with very low loading coefficient. 
The most optimal solution of fuel consumption decrease at shunting operations is shut down of diesel engine when diesel locomotive is waiting for operations. It also reduces the emissions of harmful substances by diesel locomotive.

\section{Diesel engine with a dry crankcase}

The use of diesel engine with a dry crankcase in shunting locomotives allows fixing diesel shutdown problem and its thermal state support. In railway transportation practice, there is an experience of diesel engines use with a dry crankcase at locomotives with hydro mechanical transmission (HMT).

The conceptual diagram of cooling system of diesel engine with dry crankcase based on the innovative patent [7] is provided in Figure 1.

The main condition for diesel shutdown in winter is water temperature support in the diesel cooling system, so water heating and circulation are provided as follows:

- locomotive operates in normal operations mode - water circulation is carried out by the main water pump,

- diesel engine is switched off - water circulation in the cooling system is carried out by additional pump from the power supply (segment a-4-4-b).

The switched off diesel and oil in a separate oil tank are warmed up by water heated in a special heating boiler, that operates using diesel fuel.

Water circulation is carried out along the outline - diesel - radiators - heating boiler additional pump - oil tank - cooler of boosted air-diesel. Oil from the oil tank to the diesel engine and back into the tank is pumped over pipelines by oil pumps (figure 4).

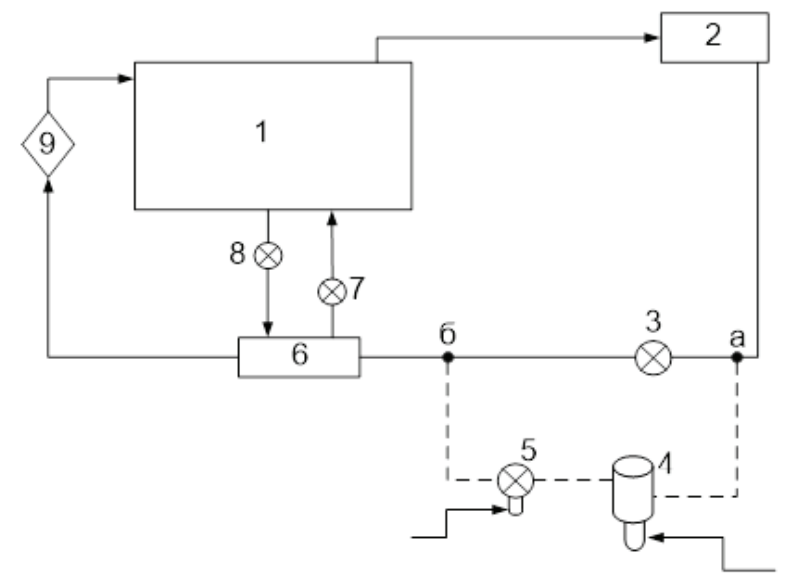

Fig. 4. Diesel cooling system operational scheme with dry crankcase. Source: authors

Legend to image: 1 -diesel, 2 - cooling radiators, 3 - main water pump, 4 - water heating boiler, 5-additional water pump, 6 - oil tank, 7-oil boost pump, 8 - oil discharge pump, 9 boost air cooler.

The electric motor of the recycling pump 5 is powered by the power supply - the energy store (ground electrical equipment or ultra-condenser). At the started diesel engine, the cooled in radiators water, that cools oil, is supplied to the oil storage tank.

The heating boiler efficiency evaluation for diesel locomotive thermal condition support is determined by comparison of fuel consumption at diesel idling and fuel consumption required for heating boiler operation [8].

Required heat for engine heating [9]: 


$$
Q=\frac{\mathrm{C}_{\mathrm{B}} \cdot \Delta \mathrm{T}}{\tau}+\alpha \cdot F \cdot \Delta T
$$

where: $C_{\partial}-$ modal diesel thermal capacity, $\mathrm{kJ} / \mathrm{grad}$

$$
\left(C_{\partial}=C_{m e t} \cdot M_{m e t}+C_{o} \cdot M_{c}+C_{o} \cdot M_{c}\right)
$$

where: $C_{m e t}, C_{o}, C_{c}$ - specific thermal capacity of metal, oil, coolant, $\mathrm{kJ} / \mathrm{kg} \bullet \mathrm{grad}$ respectively; $M_{m e t}, M_{o}, M_{c}$ - weight of metal, oil, coolant (water) respectively.

$\Delta T$-required engine heating, $\Delta T=t_{\text {кор.n. }}-t_{0}$

$T_{\text {base b. }}$-temperature of base bearings is accepted as equal to $-20^{\circ} \mathrm{C}$,

$t_{o}$-initial engine temperature is accepted as equal to $-40^{\circ} \mathrm{C}$

$t$ - engine thermal pre-starting procedure duration,

$\alpha$-heat transfer coefficient from engine surface to the environment (depending on wind speed and quality of engine warm keeping means within $15 \ldots 80 \mathrm{~kJ} / \mathrm{m}^{2} \cdot$ hour $\bullet \mathrm{grad}$ ), $F$ - area of the engine cooled surface, $\mathrm{m}^{2}$ :

$$
F=\mathrm{i} \cdot\left(\pi \cdot \mathrm{D} \cdot \mathrm{S}+\frac{2 \cdot \pi \cdot D^{2}}{4}\right) \cdot K_{n}
$$

where: $i$ - number of engine cylinders,

$\mathrm{D}, \mathrm{S}$ - diameter and engine stroke, respectively

$K_{n}$ - coefficient of actual engine surface is accepted as equal to $1.25 \ldots 1.3$.

Based on found boiler heating capacity, it is required to check the temperature of cylinders head block at the end of warming up [10].

$$
\left.t_{\text {head }}=\frac{Q \cdot \mathrm{t}}{C_{\text {head }} \cdot M_{\mathrm{A}} \cdot 60}\right)
$$

where: $c_{\text {head }}$ modal specific heat capacity of cylinders head block,

$$
C_{\text {гол }}=\frac{B}{S / D}
$$

where: $B$ - the constant coefficient accepted for the cast iron head -0.45 , aluminum alloy

casting -0.5 .

Switched off diesel thermal control is exercised by cylinder head temperature that has to be not less than $40^{\circ} \mathrm{C}$.

Fuel consumption for engine heating at a certain ambient temperature in fixed time:

$$
B_{m}=\frac{Q}{H_{u} \cdot \eta_{n}}
$$

where: $H_{u}$-fuel efficiency (for diesel fuel $42.5 \cdot 103 \mathrm{~kJ} / \mathrm{kg}$ ),

$\eta_{n}$ - heating efficiency.

Switched off diesel thermal control is exercised by cylinder head temperature that has to be not less than $40^{\circ} \mathrm{C}$.

Upon receipt of operation start command, the operator starts the diesel engine and puts locomotive in motion. 


\section{Conclusion}

Shunting operations are characterized by long-term operation of diesel locomotives at idle mode and on low-load conditions, which amounts to $60 \div 75 \%$ of their daily operation and is accompanied by an increased specific fuel consumption. The timing analysis showed that the specific consumption of diesel locomotives in shunting operations exceeded the value of the specific consumption of diesel locomotives in train operation by 10.6 times, and the load factor of the engine exceeded $\mathrm{k}=0.2 \div 0.3$. At the same time, environmental indicators deteriorate along with the increased fuel consumption.

The possible solution to this problem is by using diesel engine with dry crankcase as power installation of the diesel locomotive according to an innovative patent. № 31244, it will allow to maintain the thermal state of the muffled main diesel engine during cold weather, thereby reducing fuel consumption and emission of harmful substances with exhaust gases at idle. The technique of an estimation of a diesel thermal condition and calculation of fuel consumption of a heating boiler is given.

The paper is supported by the VEGA Agency by the Project 1/0095/16 "Assessment of the quality of connections on the transport network as a tool to enhance the competitiveness of public passenger transport system", that is solved at Faculty of Operations and Economics of Transport and Communication, University of Zilina.

This paper is supported by the research project "From horse-drawn railway to intermodal transport" within Visegrad Fund.

\section{References}

1. L. Jedlinsky, J. Caban, L. Krzywonos, S. Wierzbicki, F. Brumercik, Journal of Vibroengineering 17, 175-187 (2015)

2. V.A. Gapanovich, Railway transportation energy saving (The textbook is edited by $\mathrm{PhD}$ in Technical Sciences, 2012)

3. J. Gasparik, V. Zitricky, Transport 25, 387-393 (2010)

4. A.I. Molchanov, I.L. Povarkov, L.A. Muginstein, K.M. Popov, All-Russian Scientific Research Institute of Railway Transport Bulletin 2 (2004).

5. A.I. Volodin, E.I. Skovorodnikov, A.S. Anisimov, Case study of thermodynamic, economic and ecological characteristics of diesel locomotive engines in operation: Monograph (2011)

6. Y.E. Prosvirov, et.al, Innovative technologies in locomotive economy: Monograph (2012)

7. M.O. Mussabekov, G.B. Bakhyt, A.M. Omirbek, Innovative patent No. 31244 "Shunting diesel locomotive" (16.02.2016)

8. A.I Volodin, M. Zheldorizdat, Evaluation methods of technical condition, operational profitability and ecological safety of diesel locomotives: Monograph (2007)

9. N. Nestorova, S. Goncharuk, V. Anisimov, A. Anisimov, V. Shvartcfel, Procedia Engineering 165, 1547-1555 (2016)

10. D. Barta, M. Mruzek, M. Kendra, P. Kordos, L. Krzywonos, Advances in Science and Technology 10, 240-247 (2016) 